Témoigner Témoigner. Entre histoire et mémoire

Getuigen Revue pluridisciplinaire de la Fondation Auschwitz

$121 \mid 2015$

Violences radicales en scène

\title{
Self-narratives under communism (mainly USSR)
}

Récit de soi sous le régime communiste

Zelfvertelling onder het communisme (hoofdzakelijk in de Sovietunie)

\section{Catherine Depretto}

Translator. Bronwyn Haslam

\section{(2) OpenEdition}

1 Journals

\section{Electronic version}

URL: https://journals.openedition.org/temoigner/3565

DOI: 10.4000/temoigner.3565

ISSN: 2506-6390

This article is a translation of:

Récit de soi sous le communisme (en URSS principalement) - URL : https://journals.openedition.org/ temoigner/2345 [fr]

Publisher:

Éditions du Centre d'études et de documentation Mémoire d'Auschwitz, Éditions Kimé

Printed version

Date of publication: 1 October 2015

Number of pages: 144

ISSN: 2037-4183

\section{Electronic reference}

Catherine Depretto, "Self-narratives under communism (mainly USSR)", Témoigner. Entre histoire et mémoire [Online], 121 | 2015, Online since 01 October 2016, connection on 04 February 2022. URL: http://journals.openedition.org/temoigner/3565 ; DOI: https://doi.org/10.4000/temoigner.3565

This text was automatically generated on 4 February 2022.

Tous droits réservés 


\title{
Self-narratives under communism (mainly USSR)
}

\author{
Récit de soi sous le régime communiste \\ Zelfvertelling onder het communisme (hoofdzakelijk in de Sovietunie)
}

\section{Catherine Depretto}

Translation : Bronwyn Haslam

"Self-narratives", just like the term "communism", cover a number of phenomena that cannot be discussed exhaustively. We will content ourselves here with laying some groundwork. The recent emergence of this problematic derives from a "subjective turn" in history as well as access to new sources, following the opening of the archives of the former USSR.

2 Up until the 1990s, how individuals spoke of themselves in a communist regime (or inside a communist party) was barely considered. The dominant historiography even tended to deny all possibility of the expression of subjectivity in a society (a party) that extolled the collective and that was characterised by a will for total control over its citizens (its partisans). The discovery of a significant set of ego-documents (personal diaries first and foremost) gave access to different kinds of accounts of the self, typical to Soviet communism, and largely contributed to change our ideas.

It appears that in the USSR, including the period of Stalin's terror and the Second World War, all categories of the population maintained personal diaries in which they expressed diverse opinions, ranging from an interiorization of the categories of power to openly critical discourses (some of these journals served as incriminating evidence during the repression). Based on the legacy of the later Foucault, the attentive analysis of this material permits us to speak of a "soviet subjectivity" (Jochen Hellbeck's term), doubtlessly different from that of subjects in so-called liberal societies, but subjectivity nonetheless. This is conceived especially in terms of process, of "work on the self", revealing an active participation of subjects in the identitary offerings of the regime. While contributing to a form of servitude, these very subjects were also able to express doubts, which could develop in their taking some distance. Thus a more nuanced image 
of the subject under communism emerges (mainly in the Stalin era, 1929-1953), the study of which must highlight the interactions between official and unofficial discourses and the hybrid identifications developed by some categories of the population. Alongside diaries, other practices specific to communism fall under subjectivity: questionnaires (anketa), institutional autobiographies (avtobiografija), selfreports (samootčet), and public self-critiques (avtokritika). These are not only responses to questions but can also unfold into a veritable self-narrative, and serve to confirm that the candidate has the political capital necessary for the duties sought. The role played by the institutional biography in the cases of the P C F (French Communist Party) allows Claude Pennetier and Bernard Pudal, two French scholars, to define communism as a "biocracy".

\section{BIBLIOGRAPHY}

Depretto, Catherine, 'La "Soviet Subjectivity" : le journal personnel comme laboratoire du moi dans l'U.R.S.S. stalinienne', in Bernard Pudal and Claude Pennetier (eds.), Le sujet communiste. Identités militantes et laboratoires $d u$ « moi », coll. Histoire : Presses universitaires de Rennes, 2014, 19-34.

Foucault, Michel, The History of Sexuality, vol. 3: The Care of the Self, translated from the French by Robert Hurley, New York: Vintage Books, 1988

Garros, Véronique, Natalia Korenevskaya, \& Thomas Lahusen (eds.), Intimacy and Terror: Soviet Diaries of the 1930's, New York: New Press, 1995.

Griesse, Malte, Communiquer, juger et agir sous Staline : la personne prise entre ses liens avec les proches et son rapport au système politico-idéologique, Frankfurt am Main : Peter Lang, 2011.

Krylova, Anna, 'The Tenacious Liberal Subject in Soviet Studies', Kritika, 1 (1), 2000, 119-146.

Hellbeck, Jochen, Revolution on my Mind: Writing a Diary under Stalin, Cambridge, Mass.: Harvard University Press, 2006.

Pennetier, Claude \& Bernard Pudal (eds.), Autobiographies, autocritiques, aveux dans le monde communiste, Paris: Belin, 2002.

Studer, Brigitte, Berthold Unfried \& Irène Herrmann (eds.), Parler de soi sous Staline: la construction identitaire dans le communisme des années trente, Paris: MSH, Série Colloquium, 2002.

Studer Brigitte \& Heiko Haumann (eds.), Stalinistische Subjekte. Sujets staliniens. Stalinist Subjects, Zürich: Chronos Verlag, 2006.

\section{AUTHORS}

\section{CATHERINE DEPRETTO}

Université Paris-Sorbonne 